\title{
A GIS-BASED MULTI-CRITERIA ANALYSIS ON CROPLAND SUITABILITY IN BORNUUR SOUM, MONGOLIA
}

\author{
E. Natsagdorj ${ }^{1,2, *}$, T. Renchin ${ }^{2}$, P. De Maeyer ${ }^{1}$, R. Goossens ${ }^{1}$, T. Van de Voorde ${ }^{1}$, B. Darkhijav ${ }^{3}$ \\ ${ }^{1}$ Dept. of Geography, Ghent University, Ghent, Belgium \\ - (enkhjargal.natsagdorj, philippe.demaeyer, tim.vandevoorde, rudi.goossens)@ugent.be \\ 2 NUM-ITC-UNESCO Laboratory for Space Science and Remote Sensing, National University of Mongolia, Ulaanbaatar, Mongolia \\ - (enkhjargal_spe, tsolmon)@num.edu.mn \\ ${ }^{3}$ Dept. of Applied Mathematics, National University of Mongolia, Ulaanbaatar, Mongolia - bayand72@gmail.com
}

Commission IV, WG IV/3

KEY WORDS: cropland suitability, GIS, multi-criteria, AHP, Bornuur soum, Mongolia

\begin{abstract}
:
Agriculture is one of the most critical sectors of the Mongolian economy. In Mongolia, land degradation is increasing in the cropland region, especially in a cultivated area. The country has challenges to identify new croplands with sufficient capacity for cultivation, especially for local decision-makers. GIS applications tremendously help science in making land assessments. This study was carried out in Bornuur soum, Mongolia. The goal of this study to estimate that best suitable area for supporting crop production in Bornuur soum, using a GIS-based multi-criteria analysis (MCA) and remote sensing. GIS-based multi-criteria analysis (MCA) has been widely used in land suitability analyses in many countries. In this research, the GIS-based spatial MCA among the Analytical Hierarchy Process (AHP) method has employed. The approach was enhanced for each criterion which as soil, topography and vegetation. The opinions of agronomist experts and a literature review helped in identifying criteria (soil data, topography, water and vegetation data) that are necessary to determine areas suitable for crops. The detailed cropland suitability maps indicate that $46.12 \%$ is highly suitable for cropland, $34.68 \%$ is moderate suitable, $13.64 \%$ is marginal suitable and $5.56 \%$ is not suitable. The MCA and AHP tools play an essential role in the multi-criteria analysis. Therefore, the results of these methods allow us to estimate an appropriate area for cultivation in Bornuur soum, Tuv province. The crop suitability method implies significant decisions on different levels and the result will be used for cropland management plan to make a decision. It is an integral role in agricultural management and land evaluation. Future research should further develop this method by including socio-economic (potential citizens for agriculture, current crop growth, water resource, etc.) and environmental variables (rainfall, vegetation types, permafrost distribution, etc.) to obtain specific results. However, it could be also be applied for a single crop type (mainly barley, wheat and potato) in Mongolia.
\end{abstract}

\section{INTRODUCTION}

Agriculture is an essential economic sector in Mongolia, contributing to more than $20 \%$ of the annual GDP and representing $14 \%$ of the currency revenues (FAO, 2011). Mongolia's agro-ecosystems are incredibly vulnerable; due to global climate change, which is expected to result in higher temperatures and increased evaporation (Angerer et al. 2008 and Batima et al. 2005). These weed-covered lands induce land degradation and desertification. As a result, land degradation directly influenced by agricultural products (Gantumur et al. 2018). When they could be reclaimed, an enormous potential would improve the agro-production in the country (MFALI, 2012). At present, the total size of the arable land is estimated to be 1.2 million hectares, of which 664,300 ha is used as cropland while 561,000 ha has been abandoned (Hofmann et al. 2016). However, determining which land is the most suitable for agricultural development is essential to enhance food safety and also to stop the later food crises (Pederson et al. 2013). In Mongolia, in order to improve the agro-production and to provide food security, croplands should be enhanced in areas in which they thrive the most.

The Mongolian agricultural regions are located in the northern central part of Mongolia, which is characterized by a mountainous and forested area. The Mongolian government has been continuously increasing its expenditures for agricultural development by initiating programmes to reclaim abandoned agricultural lands, to create favourable economic conditions, to increase production and to ensure food safety (e.g. Atar 3) (Hofmann et al. 2016). The agricultural products, especially potato and wheat, slightly rose as a result of the national government programme. But the dominant vegetables' import was increased by 11.7 times, such as in $19955,438.4$ tons and it expanded to 64,107 tons in $2016.96 \%$ - $99 \%$ of which came originated from China (Otgonbayar et al. 2016). However, without the total consumption of vegetables (excluding potatoes), around $45 \%$ have been imported (Statistical Information System, 2016). That means that the Mongolian food security strongly depends on the neighbouring countries. Mongolia needs to develop its agricultural sector in agricultural management, especially main crop production.

At present, a widely used GIS application makes the land assessments more flexible, with scientific analysis (Pan, Pan, 2012). The Geographic Information Systems (GIS) is most suited to handle broad extensive data on a multiple (spatial, temporal and scale) from different sources for cost-effective and productive analysis over time (Chen et al. 2010). Therefore, there is an increasing interest in the corporation of the GIS capacity in MCA processes. The Multi-Criteria Analysis (MCA) is one of the usual valuable approaches concerning land use, environmental planning and agricultural management, too (Chen et al. 2010; Perveen et al. 2007; Kamau et al. 2015; Otgonbayar et al. 2016 and Quans et al. 2007). It is the operational instrument for supporting decision-making issues through various criteria (Grima et al. 2018 and Zabihi et al. 2019).

\footnotetext{
* Corresponding author
} 
The Analytical Hierarchy Process (AHP) is a multi-criteria analysis method that is applied with GIS, which determines the weights toward the selected criteria. AHP method has progressed via Saaty (1980) has been employed in GIS-based MCA (Carver, 1991; Marinoni, 2004; Memarbashi et al. 2017; Montgomery et al. 2016; Dragićević et al. 2014 and Pan, Pan, 2012). The latter commonly utilized in land-use suitability (Otgonbayar et al. 2016; Kamau et al. 2015; Zabihi et al. 2019 and Akinci et al. 2013). Pan and Pan (2012) applied a GISbased cropland suitability analysis using natural and socioeconomic factors to provide insight into the adaptation of measures to the local conditions regarding the crop layout and farming systems. The GIS-based multi-criteria analysis is widely used in the land suitability analyses from many countries. However, the application of the method in a cropland suitability analysis has not been performed in small Mongolian areas (such as sub-provinces), as proven, from the available literature.

The study provides to support the land manager and agronomists, including the regions' estimation based on the significant criterion that was promoted through the FAO (Food and Agricultural Organization) and adjusted at the farmers. This research provides over the determination of the cropland suitability area by means of a GIS-based AHP tool of Bornuur soum to identify the crop production suitability classes. The purpose of this research is to estimate cropland suitability that could support the crop production in Bornuur soum in the best possible way by means of a multi-criteria analysis (MCA): (1) to identify the influencing criteria for new croplands in Bornuur soum based on a literature review and to specify the classes of the criteria based on the structure of the Food and Agricultural Organization (FAO); (2) to develop a cropland suitability map and to conduct an accuracy assessment with the field measurements from Bornuur soum. There are few studies have been carried out in Mongolia using multicriteria analysis for different purposes, such as a land suitability evaluation (Myagmartseren, Myagmarjav, 2018 and Otgonbayar et al. 2016) and desertification/land degradation (Lamchin et al. 2017). In this research, it is employing the AHP tool through approach the cropland suitability over Bornuur soum that will be considered in this article.

Sustainable land-use planning is an essential condition that the evaluation of land suitability analysis surround and their suitability for a designed application concerning the grouping of certain land areas (Sarkar et al. 2014). For land crop suitability, some cognitive factors should be carried out which as moisture, digital elevation model, vegetation cover and effect of topography (Eric, Abrefa, 2011). Several types of research has been done on the land suitability analysis based on GIS, e.g. Chen et al. 2010; Perveen et al. 2007; Kamau et al. 2015; Otgonbayar et al. 2016; Pan, Pan, 2012; Quan et al. 2007; Sarkar et al. 2014; etc. In this article, our approach is demonstrated by means of a GIS-based multi-criteria study to a cropland suitability estimation in Bornuur soum, Mongolia.

\subsection{Study area}

The Mongolian agriculture is divided into five regions: Tuv, Khangai, West, East and Gobi. The total agricultural area of Mongolia measures $1,269,498$ ha $(65 \%$ of which is situated in Tuv, $11 \%$ in Khangai, $10 \%$ in the West, $14.07 \%$ in the East and $0.03 \%$ in the Gobi region) (MFALI, 2018). Therefore, we selected a study area from the most critical agricultural part in Mongolia, the Tuv region. Bornuur soum (second-level administrative subdivision) possesses an agriculturally based economy. Bornuur is located between $\mathrm{E} 48^{\circ}-49^{\circ}$ and $\mathrm{N} 106^{\circ}$ $106^{\circ} 40^{\prime}$ and the average altitude is $872-1,821$ meter above sea mean level (Natsagdorj et al. 2017). The mean annual precipitation ranges from 160 to $235 \mathrm{~mm}$, of which $85-95 \%$ occurs during the warm season (June to September). This area has lower average temperatures, ranging between 15 and $20{ }^{\circ} \mathrm{C}$ (Batima et al. 2005). Bornuur soum has a total land area of $114,483.21$ ha and is located in the central agricultural zone of Mongolia (Hugjliin Ezed NGO, 2008). It is situated in a convenient climatic region, including healthy rich soil. Bornuur soum has four soil types: Cambisols, Gleysols, Kastanozems and Leptosols (Figure 1).

Before the 1990s, the soum was the central part of the Mongolian agriculture. Agriculture was a significant employer and prominent in all sectors of the soum (Sandmann, 2010).

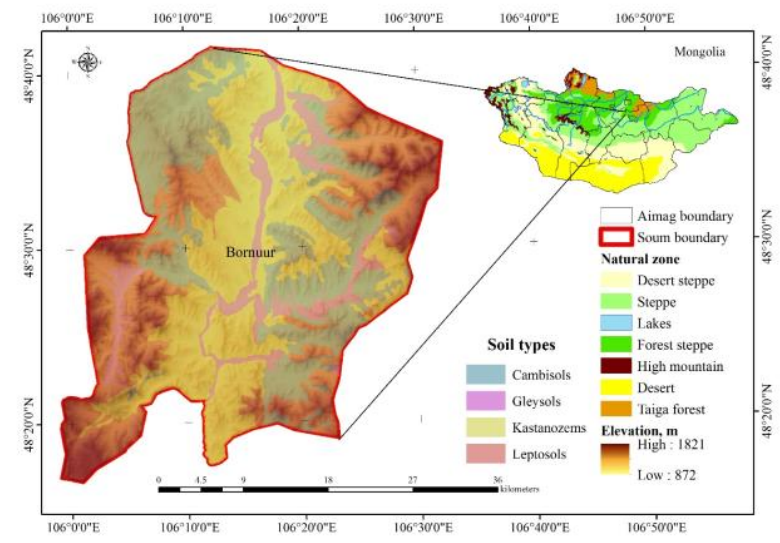

Figure 1. The Bornuur soum, Tuv province, Mongolia $\left(\mathrm{E} 48^{\circ}-49^{\circ}\right.$ and $\left.\mathrm{N} 106^{\circ}-106^{\circ} 40^{\prime}\right)$

\section{DATA COLLECTION AND PREPARATION}

Crop suitability study was utilized within this research that obtained the following sources. From literature about crop production in Mongolia, we selected vegetable areas that contain many factors such as the soil parameters (soil type, soil texture, soil $\mathrm{pH}$ and soil humus), elevation, slope, vegetation, water supply, etc. (Kamau et al. 2015; Otgonbayar et al. 2016 and FAO, 1976). The soil data and a cropland cadastral map were collected from the Land Administration and Management, Geodesy and Cartography (LAMGaC) of Mongolia (Figure 2).

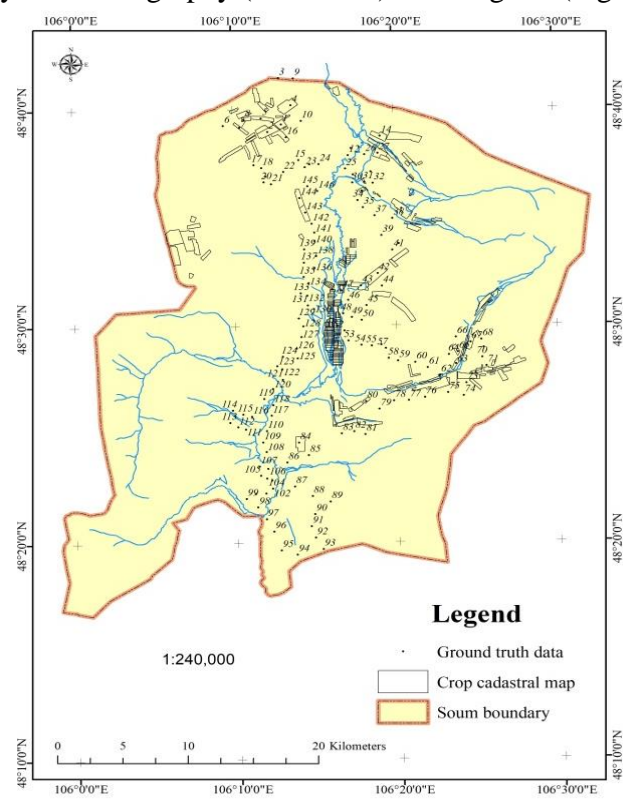

Figure 2. Cropland cadastral and field data of the Bornuur soum 
The soil thematic map on a 1:50000 scale (provided by LAMGaC) was reprocessed using ArcGIS 10.3.1 to provide thematic data and then further converted into a raster layer. The four parameters include the soil texture, soil humus, soil $\mathrm{pH}$ and soil type were selected. Bornuur soum has a suitable soil type for the cropland with the FAO structure (FAO, 1976) of the land suitability criteria. Thematic maps were acquired for each of the factors in Bornuur soum.

A field survey has been carried out archive data in Bornuur soum during 1998 - 2015. However, some field samples (36) have been collected during the field trips in July-August, 2015, with the agronomists of Bornuur soum, Tuv province. The entire 146 samples have been used from the archive and field trip in this study (Figure 2). The soum has extensive records of cropland and pasture land use, in digitally and on paper. Based on an expert's knowledge and archive notes, the field measurements were classified into a cropland suitability rate (table 1). The archive notes include information on soil and vegetation such as the organic matter, soil texture, soil moisture, soil $\mathrm{pH}$, etc. Additionally, the vegetable products of the archive data were used for a suitability classification. The suitability classes were made by local agronomists and specialists. For example, the damaged area (soil erosion, bare land) has been classified for the unsuitable. The soil texture (heavy clay), soil $\mathrm{pH}$ (7.8-8.5) and vegetation types (Artemisia frigida, Artimisia adamsii and Potentilla bifurca, etc.) are chosen as marginal suitable (52 samples). The soil texture (sand), soil humus (2$3 \%$ ), soil $\mathrm{pH}(7.5-7.8)$ and vegetation types (herb grass) are seen as moderate suitable (71 samples). The soil texture (light clay, mid-siltstone), soil humus (more than 3\%) and current croplands are considered to be highly suitable (21 samples) (Table 1). Concerning the data validation, the field samples will be utilized in the result section.

\begin{tabular}{|c|c|c|c|c|}
\hline $\begin{array}{l}\text { Field } \\
\text { samples }\end{array}$ & $\begin{array}{l}\text { Not } \\
\text { suitable }\end{array}$ & $\begin{array}{l}\text { Marginal } \\
\text { suitable }\end{array}$ & $\begin{array}{l}\text { Moderate } \\
\text { suitable }\end{array}$ & $\begin{array}{l}\text { Highly } \\
\text { suitable }\end{array}$ \\
\hline Classes & S1 & $\mathrm{S} 2$ & S3 & S4 \\
\hline Criteria & $\begin{array}{l}\text { damaged } \\
\text { area (soil } \\
\text { erosion, } \\
\text { bare land) }\end{array}$ & $\begin{array}{l}\text { Soil texture } \\
\text { (heavy } \\
\text { clay), soil } \\
\mathrm{pH}(7.8-8.5) \\
\text { and } \\
\text { vegetation } \\
\text { types } \\
\text { (Artemisia } \\
\text { frigida, } \\
\text { Artimisia } \\
\text { adamsii and } \\
\text { Potentilla } \\
\text { bifurca, etc.) }\end{array}$ & 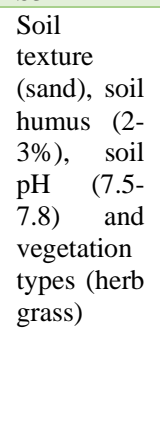 & $\begin{array}{l}\text { Soil texture } \\
\text { (light clay, } \\
\text { mid- } \\
\text { siltstone), } \\
\text { soil humus } \\
\text { (more than } \\
3 \% \text { ) and } \\
\text { current } \\
\text { croplands }\end{array}$ \\
\hline$\sum 146$ & 2 & 52 & 71 & 21 \\
\hline \multicolumn{5}{|c|}{$\begin{array}{l}\text { Note: Artemisia frigida, Artimisia adamsii and Potentilla bifurca etc: the } \\
\text { prevalence of these plants is the sign of land degradation (Bulgamaa et al. } \\
\text { 2018). }\end{array}$} \\
\hline
\end{tabular}

In order to obtain the slope and elevation data from the advanced spaceborne thermal emission and reflection (ASTER), the satellite global digital elevation model (GDEM) data were used with a 30 -meter resolution. The Landsat 8 operational land imager (OLI) with 30-meter resolution data (path 132, row 26) was used for the estimation regarding the Normalized Difference Moisture Index (NDMI) and Normalized Difference Vegetation Index (NDVI) between July / August (2014-2019) for this research. Table 2 described a data list that we applied for the benefit of this research.

\begin{tabular}{|c|c|c|}
\hline Data type & Data description & Data source \\
\hline Soil data & $\begin{array}{l}\text { Soil } \mathrm{pH} \text {, soil humus, } \\
\text { soil texture, soil type }\end{array}$ & $\begin{array}{l}\text { Land Administration and } \\
\text { Management, Geodesy and } \\
\text { Cartography (LAMGaC) }\end{array}$ \\
\hline $\begin{array}{l}\text { Digital Elevation } \\
\text { Model }\end{array}$ & $\begin{array}{l}\text { Aster GDEM V2 } \\
2011 \text {, the resolution } \\
\text { is } 30 \mathrm{~m}\end{array}$ & $\begin{array}{l}\text { U.S Geological Survey } \\
\text { (USGS) and Earth Remote } \\
\text { Sensing Data Analysis } \\
\text { Centre (ERSDAC) }\end{array}$ \\
\hline $\begin{array}{l}\text { Normalized } \\
\text { Difference } \\
\text { Vegetation Index } \\
\text { (NDVI); } \\
\text { Normalized } \\
\text { Difference } \\
\text { Moisture Index } \\
\text { (NDMI) }\end{array}$ & $\begin{array}{c}N D V I=(N I R- \\
\text { Red }) /(N I R+R e d) \\
N D M I=(N I R- \\
M I R) /(N I R+M I R)\end{array}$ & $\begin{array}{l}\text { Landsat TM/OLI satellite } \\
\text { images between } 2014 \text { and } \\
2019 \\
\text { (McDonald et al. 1998; Jin, } \\
\text { Sader, 2005; Woodcock et al. } \\
\text { 1994) }\end{array}$ \\
\hline $\begin{array}{l}\text { Cropland } \\
\text { cadastral map }\end{array}$ & $\begin{array}{l}\text { Current cadastral } \\
\text { survey }\end{array}$ & $\begin{array}{l}\text { Land Administration and } \\
\text { Management, Geodesy and } \\
\text { Cartography (LAMGaC) }\end{array}$ \\
\hline Field survey & $\begin{array}{l}146 \text { samples } \\
\text { collected using a } \\
\text { handheld GPS, } \\
\text { Accuracy } 1-5 \mathrm{~m}\end{array}$ & $\begin{array}{l}\text { Field survey and agronomist } \\
\text { expert's (1998-2015) archive } \\
\text { information }\end{array}$ \\
\hline Questionnaire & $\begin{array}{l}\text { The questionnaire } \\
\text { was prepared that are } \\
\text { related to the crop } \\
\text { suitability criterion }\end{array}$ & $\begin{array}{l}\text { Collected from the local } \\
\text { farmers and experts } \\
\text { ( } 24 \text { local farmers and } \\
\text { experts) }\end{array}$ \\
\hline
\end{tabular}

Table 2. Used data

\section{METHODOLOGY AND ANALYSIS}

The multi-criteria analysis method (based on GIS) was applied to determine the cropland suitability. Based on our literature review, only a few scientific studies have been performed on land suitability evaluation in Mongolia (Otgonbayar et al. 2016 and Myagmartseren, Myagmarjav, 2018). Although no reviews are available on the physical planning of croplands in the small regions of Mongolia using the spatial multicriteria analysis method. The process adopted for the crop suitability of the study area was executed the methodology illustrated in Figure 3. This latter illustrates the employed method in this study.

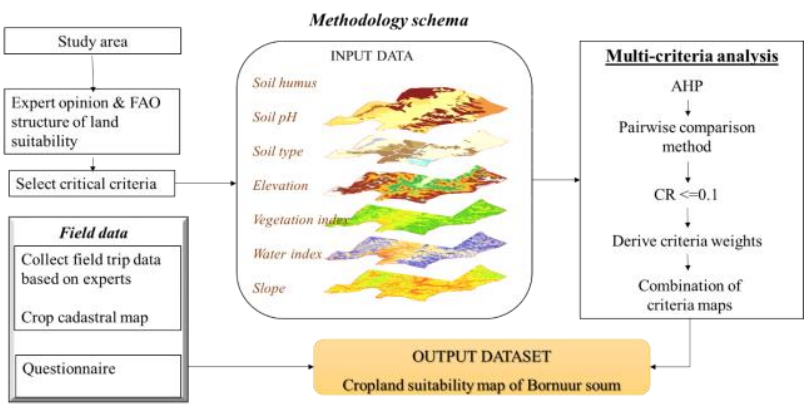

Figure 3. Flowchart methodology of the cropland suitability. FAO: Food and Agricultural Organization; AHP: Analytical Hierarchy Process; CR: Consistency Ratio

\subsection{Selection of the suitability criteria}

In the study area, the most important economic sector is agriculture, especially the crop sector. A literature review of various references and consultation of local agronomist experts helped to identify the necessary criteria (soil texture, soil type, soil $\mathrm{pH}$, soil humus, elevation (altitude), slope, vegetation and moisture) in order to estimate suitable areas for crop production. Suitability classes were made set up on formation from the FAO land suitability analysis and ranging from highly suitable, moderately suitable and marginally suitable to unsuitable in Bornuur soum, Mongolia. These classes were estimated according to the FAO guideline, literature review and agronomist expert's opinions (Table 3). 


\subsection{MCA for assigning the weight to each criterion}

The Analytical Hierarchy Process (AHP) is a standard mathematical method introduced by (Saaty, 1977) that is used when analyzing complex decision problems (Saaty, 1977 and 1990). The AHP, pairwise comparison matrix estimates the weights of each criterion $\left(w_{i}\right)$.

Pairwise comparison matrixes involve the comparison of all possible pairs of criteria in order to estimate which of them are from a higher priority. Saaty (1980) suggests a scale from 1 to 9 in which value 1 indicates that the criteria are equally essential and value 9 means that the considered criterion is superior to the other criteria (Table 4).

The crop suitability classes were assigned score 9, 7, 5 and 3, respectively. The classes with higher scores are highly suitable for crop production and by applying these scores, the estimated suitability classes and all thematic maps were reclassified.

\begin{tabular}{|c|c|c|c|c|}
\hline $\begin{array}{l}\text { Factor/Criterio } \\
\text { n }\end{array}$ & $\begin{array}{l}\text { Highly } \\
\text { suitable }\end{array}$ & $\begin{array}{l}\text { Moderately } \\
\text { suitable }\end{array}$ & $\begin{array}{l}\text { Marginally } \\
\text { suitable }\end{array}$ & $\begin{array}{c}\text { Not } \\
\text { suitable }\end{array}$ \\
\hline $\begin{array}{l}\text { Soil texture } \\
\text { (class) }\end{array}$ & $\begin{array}{c}\text { Light } \\
\text { clay \& } \\
\text { mid- } \\
\text { siltstone }\end{array}$ & Sand & Heavy clay & Clay \\
\hline Soil type & \multicolumn{4}{|c|}{ Kastanozems, Gleysols, Gambisols and Leptosols } \\
\hline Soil pH & $5.5-7.5$ & $\begin{array}{r}5.2-5.5 \\
7.5-7.8\end{array}$ & $\begin{array}{l}4.5-5.2 \\
7.8-8.5\end{array}$ & $\begin{array}{l}8.5< \\
4.5>\end{array}$ \\
\hline Soil humus $(\%)$ & $3<$ & $2.0-3.0$ & $1.0-2.0$ & $1>$ \\
\hline $\begin{array}{l}\text { Elevation } \\
\text { (meter) }\end{array}$ & $1,500>$ & $1,500-2,000$ & $2,000-3,500$ & $3500<$ \\
\hline Slope (degrees) & $0-6$ & $6-9$ & $9-12$ & $12<$ \\
\hline NDVI (index) & $0.35<$ & $0.25-0.35$ & $0.15-0.25$ & $0.15>$ \\
\hline NDMI (index) & $0.35<$ & $0.25-0.35$ & $0.15-0.25$ & $0.15>$ \\
\hline
\end{tabular}

Table 3. Criteria for the cropland suitability based on the experts and the FAO (1984) for the structure in Bornuur soum

\begin{tabular}{|c|c|c|}
\hline $\begin{array}{l}\text { Numerical } \\
\text { expression }\end{array}$ & Comparative importance & Suitability rating \\
\hline 1 & Equal importance & Unsuitable \\
\hline 3 & $\begin{array}{l}\text { Moderately importance of } \\
\text { one factor covering another }\end{array}$ & Marginal suitable \\
\hline 5 & $\begin{array}{l}\text { The strong or crucial } \\
\text { importance }\end{array}$ & Moderate suitable \\
\hline 7 & Extreme importance & Highly suitable \\
\hline 9 & Extremely importance & \\
\hline $2,4,6,8$ & \multicolumn{2}{|l|}{ Moderate values } \\
\hline
\end{tabular}

Table 4. Scale concerning pairwise correlation (Saaty, 1990 and 2006; Burnside et al. 2002)

\subsection{Weighted linear combination (WLC) estimation of the} criteria

We rated all criterion set up on the information from the literature review and the local experts.

In order to estimate the related criteria weight, the AHP method has been applied to compute every criterion weight. A pairwise comparison matrix (PWCM) held taken using information from the literature review and the local experts concerning determining the value of weights regarding each related criterion through another. In AHP method, a consistency index intervenes in the Consistency Ratio (CR), has been applied to designate the possibility that matrix judgements obtained a randomly created by means of equation (1) (Hossain et al. 2013):

$$
C R=\frac{C I}{R I}
$$

, where $R I$ is mean of the resulting consistency index depending on the quantity of the matrix, given by Saaty (Hossain et al. 2013 and Sanare et al. 2015).

The $C R$ index represents the consistency of the PWCM. If the $C R$ exceeds 0.1 , that weighting rate is unacceptable and if the ratio value is lower than 0.1 , that weighting rate means acceptable (Hossain et al. 2013). The Consistency Index $(C I)$ is described in equation (2):

$$
C I=\frac{m_{\max }-n}{n-1}
$$

, where $C I$ stands for the Consistency Index, $m_{\max }$ the maximum own value and $n$ represents the matrix order.

After estimating the weights of the values of the criteria using the AHP tool, all criteria maps have been overlaid applying the cropland suitability (equation 3). Cropland suitability map could be calculated from the Weighted Linear Combination (WLC) of criteria used by the equation (3). The WLC method is one of the most commonly used in GIS-MCA (Malczewski, 2000)

$$
C S=\sum_{i} w_{i} * c_{i}
$$

, where $C S$ represents the final cropland suitability value, $w_{i}$ shows the weight of criterion $i$ and $c_{i}$ demonstrates the standardized criterion score $i$ (Gorsevski et al. 2006).

The weights of seven criterion and ranks represent in Table 5, according to the literature review and local experts' interviews. We have estimated $\mathrm{CR}=0.094$ and this shows that the judgement has a reasonable consistency. The $w_{i}$ is the weight value for each criterion and normalizes the amount of the sections facing unity while $\sum w_{i}=1$ (Flitter et al. 2013).

\begin{tabular}{|l|l|c|c|}
\hline Id & Name of the criteria & Ranking & Weight \\
\hline $\mathbf{1}$ & Soil texture $(S T)$ & 2 & 0.193 \\
\hline 2 & Soil pH $(p H)$ & 7 & 0.223 \\
\hline 3 & Soil humus $(S H)$ & 1 & 0.132 \\
\hline 4 & Elevation $(E)$ & 5 & 0.158 \\
\hline 5 & Slope $(S l)$ & 4 & 0.106 \\
\hline 6 & NDMI $(N D M I)$ & 3 & 0.109 \\
\hline 7 & NDVI $(N D V I)$ & 0.078 \\
\hline \multicolumn{2}{|l|}{ Consistency ratio $(\mathrm{CR}): 0.094$} & & \\
\hline
\end{tabular}

\section{Consistency ratio (CR): 0.094}

Table 5. Defined ranking and weights of the criteria

\subsection{Accuracy assessment}

The confusion matrix can provide different measures of accuracy. For the accuracy assessment of the cropland suitability map, the confusion matrix has been used. A confusion matrix is usually applied as a quantitative method of characterizing image classification accuracy. It is a table that shows the connection between the output map and the field measurements (Story, Congalton, 1986).

\section{RESULTS AND DISCUSSION}

In order to obtain the weighted linear combination of different criteria for the cropland suitability in Bornuur soum, seven criteria images were overlaid applying the cropland suitability (equation 4).

$C S=w_{i} * S T+w_{i} * p H+w_{i} * S H+w_{i} * E+w_{i} * S l+w_{i} *$ $N D V I+w_{i} * N D M I$ 
, where: $C S$ - Cropland Suitability, $w_{i}=\mathrm{j} ; \sum w_{i}=1.0$, a weighted index for influencing criterion, $S T$ - Soil Texture, $p H$ - Soil PH, $S H$ - Soil Humus, $S l$ - Slope, $E$ - Elevation, $N D V I$ - Normalized Difference Vegetation Index, NDMI - Normalized Difference Moisture Index

In this research, a multi-criteria analysis was applied to Bornuur soum using an ArcGIS weighted overlay tool. In the suitability analysis, weights measure the influence of the considered suitability criteria (Flitter et al. 2013), which are shown in Table 3. Multi-criteria analysis was created mentioning the following equations (5). The tool works with multiple raster inputs, representing several criteria. In this suitability model, the output values from the approach could range from unsuitable to highly suitable. The $w_{i}$ stands for the weighted indexes (Table 5) for each criterion on cropland suitability in Bornuur soum. Thus, the weighted linear combination of criteria through equation (5) has been estimated.

$$
C S=0.19 * S T+0.22 * p H+0.13 * S H+0.16 * E+0.11 * S l
$$$$
+0.08 * N D V I+0.11 * N D M I
$$

In the present case, the cropland suitability classes consisting of four ranges applied in this study adjusted the FAO system (FAO, 1976). They are specified as: highly suitable, moderately suitable, marginal suitable and not suitable. Seven criteria (soil texture, soil $\mathrm{pH}$, soil humus, elevation, slope, NDVI and NDMI) were chosen based on the study objective and in particular the data availability. The soil thematic data were converted into raster layers and prepared in ArcGIS. The elevation and slope were produced from DEM. The NDVI and NDMI were calculated from the Landsat satellite images with a $30 \mathrm{~m}$ resolution during 2014-2019. All selected criteria were classified into 4 classes as an integer raster displaying different cropland suitability set up on the origin rates in Table 3 . The results of this study provide all criteria, as shown in Figure 4.
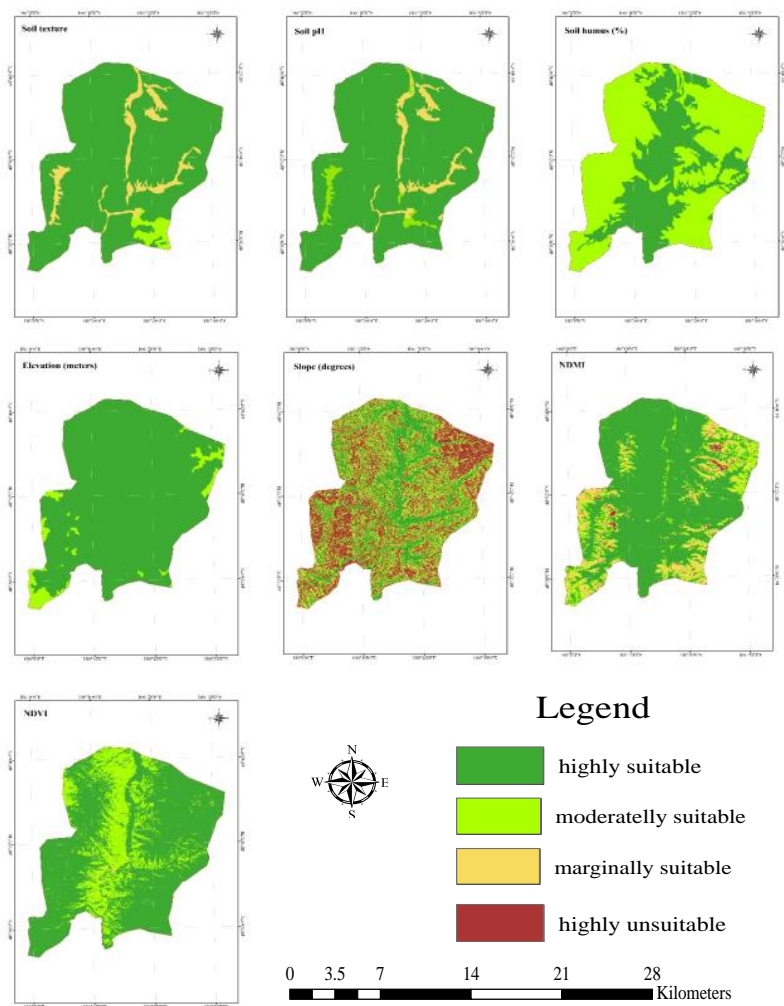

Figure 4. Criteria maps for the cropland suitability which as classified via table 3 .
The best suitable areas for cropland signify indicated within green colour and unsuitable areas occur in red (Figure 4). Given the validation, we applied a confusion matrix evaluation between the output maps regarding the cropland suitability and field data.

The output maps for the crop suitability apply several criteria such as the soil texture, $\mathrm{pH}$, soil humus, elevation, slope, NDMI and NDVI. The soil type criteria were not applied for the criteria on cropland suitability in the study area. Soum has suitable soil types for the cropland that are maintained in the FAO structure of the land suitability criteria (FAO, 1976). The output map for suitability described four classes with the relative suitability for cropland. These classes are explained as follows: unsuitable in red, marginal suitable in light yellow, moderate suitable in light green and highly suitable in dark green (Figure 5). The output map from the cropland suitability area approach is demonstrated in Figure 5.

In order to make validations, the output map from the approach was compared with the crop cadastral map from the Agency for Land Administration and Management, Geodesy and Cartography and the field data from the field survey, respectively. Firstly, the cropland cadastral map overlapped the output suitability map. Currently, there are 259 croplands in Bornuur soum in total. Around $95 \%$ of the croplands are located in the highly suitable and moderate suitable part of the output map of suitability.

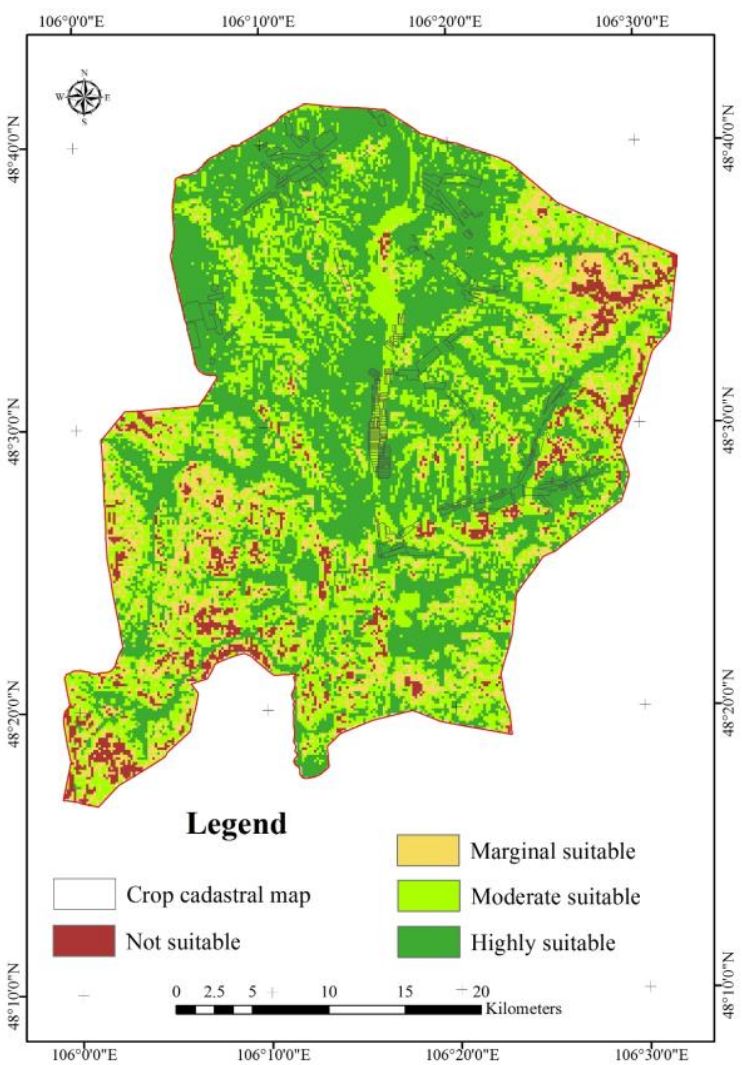

Figure 5. The output map of the cropland suitability in Bornuur soum

The result of the cropland suitability analysis reveals that 46.12 $\%$ is highly suitable for cropland, $34.68 \%$ is moderate suitable, $13.64 \%$ marginally suitable and $5.56 \%$ unsuitable (Figure 5). Additionally, the questionnaires data related to the cropland suitability criteria were collected from the local farmers and experts. During the study, we gathered several questionnaires from the local farmers and experts (24 respondents) during 
2019. The questionnaire was prepared as a patch and selection test that included twelve questions which are related to the criteria on crop suitability (Figure 6).

The questionnaire was prepared for the local farmers and the questions based on a classification of criteria. The latter comprised questions about soil parameters (soil pH, soil texture, soil type, soil moisture), slope and elevation made on the form (Figure 6). The result reveals that $74.2 \%$ proves highly suitable for cropland, $19.2 \%$ is moderate suitable, $1.67 \%$ marginal suitable and $5.0 \%$ is not necessary (Table 6).

\begin{tabular}{|l|c|c|c|c|c|c|}
\hline $\begin{array}{l}\text { Question } \\
\text { High }\end{array}$ & $p H$ & STY & STE & SM & Sl & $E$ \\
\hline $\begin{array}{l}\text { suitable } \\
\text { Moderate }\end{array}$ & 14 & 22 & 12 & - & 21 & 20 \\
\hline Marginal & - & - & 2 & - & - & - \\
\hline $\begin{array}{l}\text { Not } \\
\text { suitable }\end{array}$ & - & - & - & - & - & - \\
\hline $\begin{array}{l}\text { Not } \\
\text { necessary }\end{array}$ & & 2 & 1 & - & 3 & - \\
\hline $\begin{array}{l}\text { Note: pH - soil pH, STY- soil type, STE-soil texture, SM-soil } \\
\text { moisture, Sl-slope, E- elevation }\end{array}$
\end{tabular}

Table 6. Results of the questionnaire

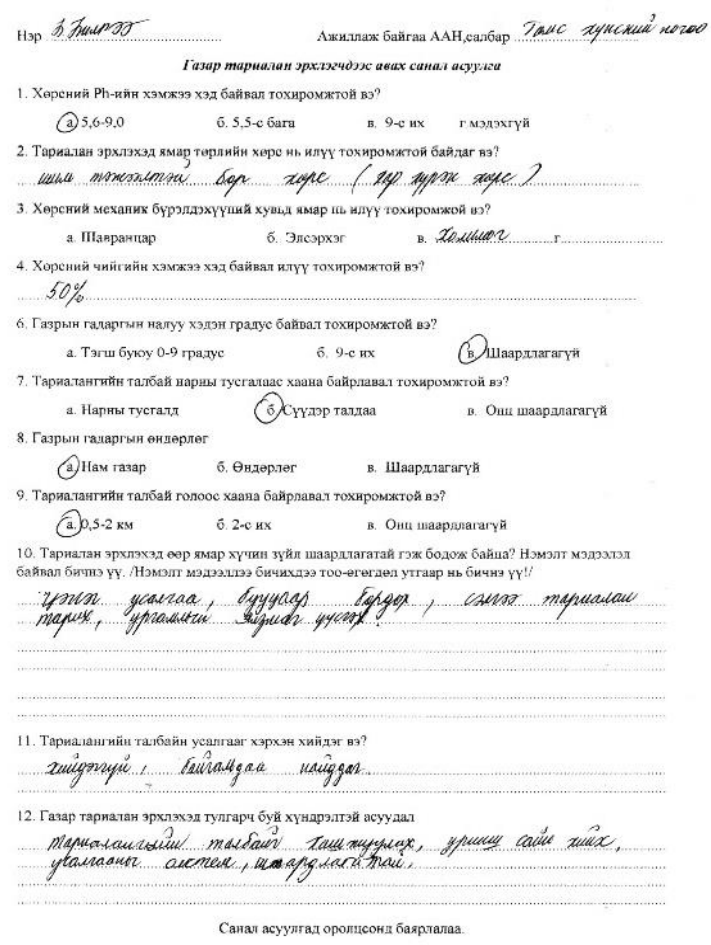

Figure 6. Questionnaire form (in Mongolian)

The field data were classified into four levels (Table 1), the same as for the crop suitability output map in the study area. The output crop suitability map was sufficiently accurate for field data. Then, a validation was made by means of the confusion matrix evaluation. A strong relation $(71.23 \%)$ is noticeable between the output map of suitability and the field survey (Table 7). The overall accuracy compared with the field data measures $71.23 \%$ of the pixels that are identically classified for both datasets. The most representative and complied proof was the kappa coefficient of 0.56 , which describes a moderate agreement within the output crop suitability and the field data.

\begin{tabular}{|c|c|c|c|c|c|c|c|c|}
\hline & \multicolumn{4}{|c|}{ Classes derived from the MCA } & \multirow{2}{*}{ 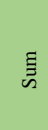 } & \multirow{2}{*}{ 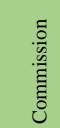 } & \multirow{2}{*}{ 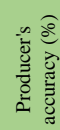 } \\
\hline & & \begin{tabular}{|c} 
Not \\
suitable
\end{tabular} & $\begin{array}{l}\text { Marginal } \\
\text { suitable }\end{array}$ & $\begin{array}{l}\text { Moderate } \\
\text { suitable }\end{array}$ & $\begin{array}{l}\text { Highly } \\
\text { suitable }\end{array}$ & & & \\
\hline \multirow[t]{2}{*}{ : } & $\begin{array}{c}\text { Not } \\
\text { suitable }\end{array}$ & 6 & 2 & & & 8 & 0.25 & 75.0 \\
\hline & $\begin{array}{l}\text { Marginal } \\
\text { suitable }\end{array}$ & 1 & 17 & 7 & 8 & 33 & 0.48 & 51.5 \\
\hline \multirow{2}{*}{ 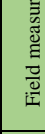 } & $\begin{array}{l}\text { Moderate } \\
\text { suitable }\end{array}$ & & 1 & 28 & 9 & 38 & 0.26 & 73.7 \\
\hline & $\begin{array}{l}\text { Highly } \\
\text { suitable }\end{array}$ & & & 14 & 53 & 67 & 0.21 & 79.1 \\
\hline \multicolumn{2}{|r|}{ Sum } & 7 & 20 & 49 & 70 & 146 & & \\
\hline \multicolumn{2}{|c|}{ Omission } & 0.14 & 0.15 & 0.43 & 0.32 & & & \\
\hline \multicolumn{2}{|c|}{$\begin{array}{c}\text { User's } \\
\text { accuracy (\%) }\end{array}$} & 85.71 & 85.00 & 57.14 & 67.92 & & & \\
\hline
\end{tabular}

Table 7. Confusion matrix and accuracy estimates for the cropland suitability map.

\section{CONCLUSION}

A GIS-based multicriteria analysis has recently been put to use for an agricultural land suitability evaluation. The newly created area selection provided by means of the multi-criteria analysis method shows unbeaten future prospects in that direction, especially for the small provinces. These methods will allow a more precise, rapid and low-priced environmental and agricultural management activity.

Recent agricultural studies have maintained the developing approach for the cropland suitability rating by means of the multi-criteria evaluation method. Mongolia also needs satellite image processing for the cropland studies, as it is valuable for agricultural and land management.

In Bornuur soum, as all soil types are suitable for cropland. We selected other criteria such as soil parameters, topography, vegetation and moisture index in this research. The multicriteria analysis was applied for the cropland suitability approach based on GIS in Bornuur soum. GIS has proven to be an effective, operational tool for complex evaluation processes of cropland suitability (Pan, Pan, 2012). From this study, we executed an estimation of the cropland suitability approach, using GIS in the agricultural area in Mongolia.

Our study evaluated the cropland extent in Bornuur soum, investigating the cropland suitability map based upon various criteria before-mentioned that vegetation, soil parameters, moisture and topography. The results shown in the output map are reasonable. The agreement with the crop cadastral map amounts to approximately $95 \%$, from the questionnaire $74 \%$ of the respondents chose the highly suitable answer while $71 \%$ of the field data (table 7), respectively. The conducted cropland suitability maps confirmed that $46.12 \%$ is highly suitable for cropland, $34.68 \%$ moderate suitable, $13.64 \%$ is marginal suitable and $5.56 \%$ unsuitable (Figure 5).

The decision methods that are handled in the land-use evaluation problems cannot be randomly selected without appropriate justification (Dujmovi et al. 2009; Chen et al. 2010 and Zabihi et al. 2019). In this study, a multi-criteria analysis has been established in an agricultural region in the central part of Mongolia. The innovation of this research was meant to develop suitable cropland regions, which utilized both satellite images and GIS. The study employed the elevation and slope factors for the forested mountainous and agricultural areas. It can be applied to various regions and environments. The additional factors should also be considered. The approach could function as an advantageous indicator so as to take further agricultural management decisions and to advise the regional decision-makers. The advantages of this approach are to allow 
researchers to determine new, suitable agricultural regions in various areas.

The result of this research could be used for the soum government in order to advise local farmers in suitable areas. In terms of practical application, this approach proves to be a useful tool to obtain reliable and reasonable agricultural studies, thereby providing valuable information for the decision-makers and farmers. In the future, this study could be referred to map the land suitability of other soums and over the country with further and more processed parameters. The cropland suitability databases in the agricultural sector will ensure the essential reliability of the estimates and forecasts, which will undoubtedly be helpful in the process of planning and policymaking.

\section{ACKNOWLEDGEMENTS}

The first author is very grateful to the European Union ERASMUS-IMPAKT program scholarship allowing her to pursue her research at the Ghent University, Belgium. Also, we are thankful to the local agricultural specialist (Altankhundaga, B.) and local farmers who have attended the survey in Bornuur soum, Tuv province, Mongolia.

\section{REFERENCES}

Akinci, H., Özalp, A.Y., Turgut, B., 2013: Agricultural Land Use Suitability Analysis Using GIS and AHP Technique. Computers and Electronics in Agriculture, 97(2013), 71-82.

Angerer, J., Han, G., Fujisaki, I., Havstad, K., 2008: Climate Change and Ecosystems of Asia with Emphasis on Inner Mongolia and Mongolia. Rangelands, 30(3), 46-51.

Batima, P., Gombluudev, P., Natsagdorj, L., Erdenetsetseg, B., 2005. Observed Climate Change in Mongolia. Report, Ulaanbaatar, Mongolia.

Bulgamaa, D., Sunjidmaa, S., Bestelmeir, B., Budbaatar U., 2018. National Pasture State Report of Mongolia. Report, Ulaanbaatar, Mongolia.

Burnside, N.G., Smith, R.F., Waite, S., 2002: Habitat Suitability Modelling for Calcareous Grassland Restoration on the South Downs, United Kingdom. Journal of Environmental Management, 65(2), 209-221.

Carver, S.J., 1991: Integrating Multi-Criteria Evaluation with Geographical Information Systems. International Journal of Geographical Information Systems, 5(3), 321-339.

Chen, Y., Yu, J., Khan, S., 2010: Spatial Sensitivity Analysis of Multi-Criteria Weights in GIS-Based Land Suitability Evaluation. Environmental Modelling and Software, 25(2010), 1582-1591.

Dragićević, S., Lai, T., Balram, S., 2014: GIS-Based Multicriteria Evaluation with Multiscale Analysis to Characterize Urban Landslide Susceptibility in Data-Scarce Environments. Habitat International, 45(P2), 114-125.

Dujmovi, J., De Tré, G., Dragi, S., 2009. Comparison of Multicriteria Methods for Land-Use Suitability Assessment. IFSA-EUSFLAT 2009, 1404-1409.

Eric, K.F., Abrefa, K.N., 2011: Digital Soil Mapping in GIS
Environment for CropLand Suitability Analysis. International Journal of Geomatics and Geosciences, 2(1), 133-146.

FAO., 1976. A Framework for Land Evaluation. Food and Agriculture Organization of the United Nations, Rome.

FAO., 2011. Mongolia and FAO Achievements and Success Stories. Report, Rome, Italy.

Gantumur, B., Wu, F., Vandansambuu, B., Munaa, Ts., Itiritiphan, F., Zhao, Y., 2018: Land Degradation Assessment of Agricultural Zone and Its Causes: A Case Study in Mongolia. Proc. of SPIE. Remote Sensing for Agriculture, Ecosystems and Hydrology., 107831W, 1-16. doi.org/10.1117/12.2325164.

Gorsevski, P.V., Jankowski, P., Gessler, P.E., 2006: An Heuristic Approach for Mapping Landslide Hazard by Integrating Fuzzy Logic with Analytic Hierarchy Process. Control and Cybernetics, 35(1), 121-146.

Grima, N., Singh, S.J., Smetschka, B., 2018: Improving Payments for Ecosystem Services (PES) Outcomes through the Use of Multi-Criteria Evaluation (MCE) and the Software OPTamos. Ecosystem Services, 29(2018), 47-55.

Hofmann, J., Tuul, D., Enkhtuya, B., 2016: Agriculture in Mongolia under Pressure of Agronomic Nutrient Imbalances and Food Security Demands: A Case Study of Stakeholder Participation for Future Nutrient and Water Resource Management. Integrated Water Resources Management: Concept, Research and Implementation, 471-514. doi.org/10.1007/978-3-319-25071-7_19.

Hossain, M.S., Rahman, M.F., Thompson, S., Nabi, M.R., Kibria, M.M., 2013: Climate Change Resilience Assessment Using Livelihood Assets of Coastal Fishing Community in Nijhum Dwip, Bangladesh. Science and Technology, 21(2), 397-422.

Hugjliin Ezed NGO., 2008. Socio-Economic Survey in Bornuur Soum. Report, Ulaanbaatar, Mongolia.

Jin, S., Sader, S.A., 2005: Comparison of Time Series Tasseled Cap Wetness and the Normalized Difference Moisture Index in Detecting Forest Disturbances. Remote Sensing of Environment, 94(3), 364-372.

Kamau, S.W., Kuria, D., Gachari, M.K., 2015: Crop-Land Suitability Analysis Using GIS and Remote Sensing in Nyandarua County, Kenya. Journal of Environment and Earth Science, 5(6), 121-131.

Lamchin, M., Lee, W.K., Jeon, S., Lee, J.Y., Song, C., Piao, D., Lim, C.H., Khaulenbek, A., Navaandorj, I., 2017: Correlation between Desertification and Environmental Variables Using Remote Sensing Techniques in Hogno Khaan, Mongolia. Sustainability 9(4), 581.

Malczewski, J., 2000: On the Use of Weighted Linear Combination Method in GIS: Common and Best Practice Approaches. Transactions in GIS 4(1), 5-22.

Marinoni, O., 2004: Implementation of the Analytical Hierarchy Process with VBA in ArcGIS. Computers and Geosciences 30(6), 637-646. 
McDonald, A.J., Gemmell, F.M., Lewis, P.E., 1998: Investigation of the Utility of Spectral Vegetation Indices for Determining Information on Coniferous Forests. Remote Sensing of Environment, 66(3), 250-272.

Memarbashi, E., Azadi, H., Barati, A.A, Mohajeri, F., Passel, S.V, Witlox, F., 2017: Land-Use Suitability in Northeast Iran: Application of AHP-GIS Hybrid Model. ISPRS International Journal of Geo-Information, 6(12), 396.

MFALI., 2018. Cultivated Land, Ministry of Food, Agriculture and Light Industry. Report 2018. Ulaanbaatar, Mongolia.

MFALI., 2012. Agricultural Policy of Mongolia Enhancing Productivity of Agricultural Sector. Report, Ulaanbaatar, Mongolia

Montgomery, B., Dragićević, S., Dujmović, J., Schmidt, M., 2016: A GIS-Based Logic Scoring of Preference Method for Evaluation of Land Capability and Suitability for Agriculture. Computers and Electronics in Agriculture, 124(2016), 340-353.

Myagmartseren, P., Myagmarjav, I., 2018: Cropland Suitability Assessment and Confusion Matrix Evaluation with GIS. Mongolian Journal of Agricultural Sciences, 21(02), 78-83.

Otgonbayar, M., Atzberger, C., Chambers, J., Amarsaikhan, D., Böck, S., Tsogtbayar, J., 2016: Land Suitability Evaluation for Agricultural Crop-Land in Mongolia Using the Spatial MCDM Method and AHP Based GIS. Journal of Geoscience and Environment Protection, 5(09) 238-263.

Pan, G., Pan, J., 2012: Research in Crop Land Suitability Analysis Based on GIS. IFIP Advances in Information and Communication Technology. 369. doi.org/10.1007/978-3-64227278-3_33.

Helmut, F., Laube, P., Luscher, P., Rogers, S., Hagi, S., 2013: Suitability Analysis. Geographic Information Technology Training Alliance, University of Zurich, Switzerland.

Pederson, N., Leland, C., Nachin, B., Hessl, A.E., Bell, A.R., Martin-Benito, D., Saladyga, T., Suran, B., Brown, P.M., Davi, N.K., 2013: Three Centuries of Shifting Hydroclimatic Regimes across the Mongolian Breadbasket. Agricultural and Forest Meteorology, 178-179(2013), 10-20.

Perveen, M.F., Nagasawa, R., Uddin, M.I., Delowar, H.K., 2007. Crop-Land Suitability Analysis Using a Multi-Criteria Evaluation and GIS Approach. Symposium on Digital Earth.

Quan, B., Zhu, H.J., Chen, S.L., Romkens, M.J.M., Li, B.C., 2007: Land Suitability Assessment and Land Use Change in Fujian Province, China. Pedosphere, 17(4), 493-504.

Saaty, T.L., 1990: How to Make a Decision: The Analytic Hierarchy Process. European Journal of Operational Research, 48(1), 9-26.

Saaty, T.L., 2006: The Analytic Network Process. Decision Making with the Analytic Network Process. Springer, Boston, MA.

Saaty, T.L., 1977: A Scaling Method for Priorities in Hierarchical Structures. Journal of Mathematical Psychology,
$15(3), 231-281$.

Saaty, T.L., 1980: The Analytic Hierarchy Process. Mcgraw Hill Publisher, New York.

Sanare, J.E., Ganawa, E.S., Salih, A.A., 2015: Wildlife Habitat Suitability Analysis at Serengeti National Park (SNP), Tanzania Case Study Loxodonta Sp. Journal of Ecosystem and Ecography, 5(3), 164.

Sandmann, R., 2010. Artisanal and Small-Scale Gold Mining in Mongolia - A Contribution to Sustainable Development? Study on Socio-Economic Changes in Bornuur Soum Centre after Foundation of XAMO Company. Report, Ulaanbaatar, Mongolia.

Sarkar, A., Ghosh, A., Banik, P., 2014: Multi-Criteria Land Evaluation for Suitability Analysis of Wheat: A Case Study of a Watershed in Eastern Plateau Region, India. Geo-Spatial Information Science, 17(2), 119-128.

Statistical Information System., 2016. Mongolian Customs Food Vegetables Import Data between 1995-2016 years. Report, Ulaanbaatar, Mongolia.

Story, M., Congalton, R.G., 1986: Accuracy Assessment: A User's Perspective. Photogrammetric Engineering and Remote Sensing, 52(3), 397-399.

Woodcock, C.E., Collins, J.B., Gopal, S., Jakabhazy, V.D., Li, X., Macomber, S., Ryherd, S., 1994: Mapping Forest Vegetation Using Landsat TM Imagery and a Canopy Reflectance Model. Remote Sensing of Environment, 50(3), 240-254.

Zabihi, H., Alizadeh, M., Kibet, L.P., Karami, M., Shahabi, H., Ahmad, A., Nor Said, M., Lee, S., 2019: GIS Multi-Criteria Analysis by Ordered Weighted Averaging (OWA): Toward an Integrated Citrus Management Strategy. Sustainability, 11(4), 1009. 